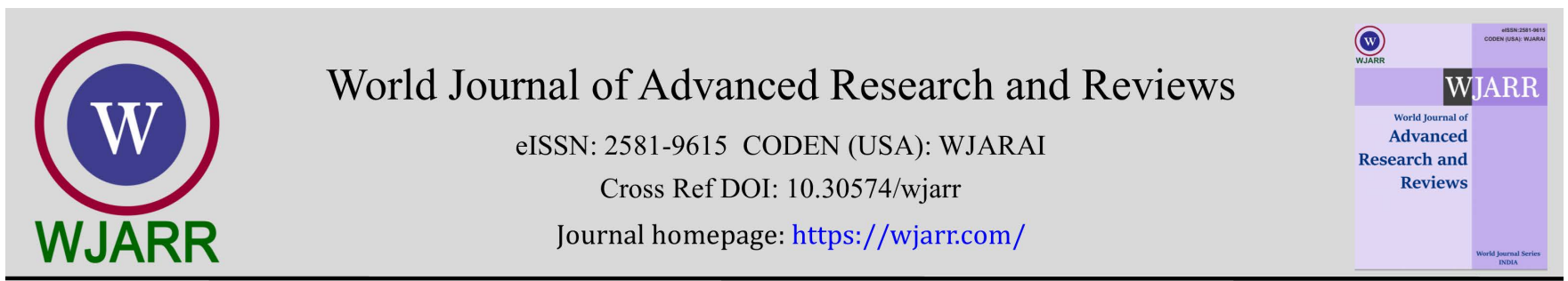

(RESEARCH ARTiClE)

Check for updates

\title{
Factors Influencing market access of green pomelo farmers in Ben Tre Province
}

\author{
Nguyen Quoc Nghi *, Le Kim Thanh and La Nguyen Thuy Dung \\ School of Economics, Can Tho University, Vietnam.
}

World Journal of Advanced Research and Reviews, 2021, 12(01), 256-260

Publication history: Received on 04 September 2021; revised on 12 October 2021; accepted on 14 October 2021

Article DOI: https://doi.org/10.30574/wjarr.2021.12.1.0511

\begin{abstract}
The study goal is to determine factors affecting the market access of green pomelo farmers in Ben Tre Province. The study collected data from 148 households growing green pomelo in Chau Thanh, Mo Cay Bac, Giong Trom, and Cho Lach Districts. The study has demonstrated six impacting factors to the market access of pomelo farmers by the logit regression. They include age, training, telephone, connection, distance, and acreage. In particular, training is the most affecting factor to the market access of green pomelo growers in Ben Tre Province.
\end{abstract}

Keywords: Market access; Farmer; Gree pomelo; Ben Tre Province

\section{Introduction}

Green skin pomelo is one of the specialties and high-quality fruits in Ben Tre Province. In 2020, Ben Tre Province owns more than 7,200 hectares of green pomelo. In which, about 4,800 hectares of pomelo are bearing fruit. They produce 57,000 tons of pomelo/year, leading the productivity of the Mekong Delta region. Green pomelo trees are grown concentrated in districts such as Chau Thanh, Mo Cay Bac, Giong Trom, Cho Lach, and Ben Tre City. To develop this type of specialty tree, the province has built a planning map of green pomelo growing areas. The locality selected highstandard pomelo lines, built the brand "Ben Tre", and created a promotional website. Meanwhile, climate change and pests have threatened the yield and quality of green skin pomelo in recent years. Besides, the unstable output market and the competitive pressure of substitute products harm farmers' income sources. One of the main reasons for this situation is that farmers' accessibility to the market is limited. Therefore, this study is conducted to identify factors affecting farmers' market access, thereby proposing recommendations to improve the market accessibility for green pomelo growers in Ben Tre Province.

\section{Theoretical Framework and Research Model}

According to Kleih et al. (1999) [1], the market access reflects the resource capability of farmers to communicate with input providers and their ability to negotiate with buyers to sell products at a profitable rate. As presented by Cuong in 2005 [2], market access is the level of difficulty that farmers go deeply into the manufacturing input suppliers and the product output markets. Bly (2006) [3] said that market access is a process of finding, detecting, and evaluating the market demand, then making the production plan, seeking target markets, penetrating the market, and approaching customers to achieve business goals.

The literature review has shown that there have been many studies related to farmers' market access and factors affecting their accessibility. It can mention several authors such as Van Schalkwyk et al. (2007) [4], Yamano and Kijima (2011) [5], Amaya and Alwang (2011) [6], Kuma (2012) [7], Nghi and Nam (2014) [8]. Based on relevant studies

\footnotetext{
${ }^{*}$ Corresponding author: Nguyen Quoc Nghi

School of Economics, Can Tho University, Vietnam.

Copyright (C) 2021 Author(s) retain the copyright of this article. This article is published under the terms of the Creative Commons Attribution Liscense 4.0.
} 
combined with group discussions (nine farmers growing green pomelo), the model research on factors affecting market access of green pomelo farmers in Ben Tre Province is proposed below.

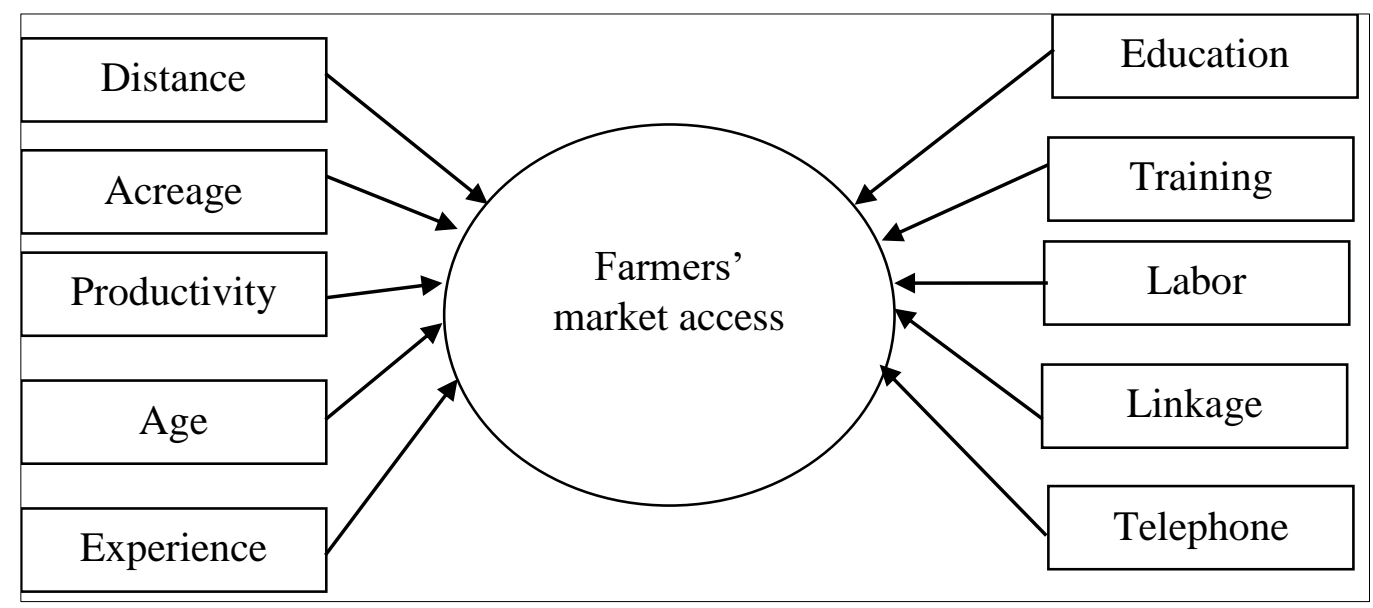

Figure 1 Proposed research model

To test the research model, the study applied the logit regression with the established equation as:

$\mathrm{MA}=\beta_{0}+\beta_{1} \mathrm{DIS}+\beta_{2} \mathrm{ACR}+\beta_{3} \mathrm{PRO}+\beta_{4} \mathrm{AGE}+\beta_{5} \mathrm{EXP}+\beta_{6} \mathrm{EDU}+\beta_{7} \mathrm{TRA}+\beta_{8} \mathrm{LAB}+\beta_{9} \mathrm{LIN}+\beta_{10} \mathrm{TEL}$

In which, the measurement variable is MA. This variable measures the farmers' ability to access input and output markets. The MA variable receives the value 1 if the farmer has a high capability to access the market (updating market information continuously and grasping prices quickly). The MA variable takes the value 0 if the farmer's market access is low. The independent variables are explained in Table 1.

Table 1 Interpretation of independent variables in the research model

\begin{tabular}{|c|c|c|c|}
\hline Variable & Calculation unit & Description & Expectation \\
\hline AGE & Year & $\begin{array}{l}\text { Age: taking the value of the direct producer's age, up to the study } \\
\text { time }\end{array}$ & + \\
\hline EDU & Year & $\begin{array}{l}\text { Education attainment: taking the value of schooling years of the } \\
\text { direct producer, up to the present }\end{array}$ & + \\
\hline EXP & Year & $\begin{array}{l}\text { Experience: taking the value of experience years of green pomelo } \\
\text { direct producer, up to the present }\end{array}$ & + \\
\hline ACR & $\mathrm{m}^{2}$ & $\begin{array}{l}\text { Acreage: taking the value of green pomelo cultivated land of the } \\
\text { farmer }\end{array}$ & + \\
\hline PRO & $\mathrm{Kg} / 1000 \mathrm{~m}^{2}$ & $\begin{array}{l}\text { Productivity: taking the value of the total output harvested in the } \\
\text { studied crop }\end{array}$ & + \\
\hline LIN & $0 / 1$ & $\begin{array}{l}\text { Linkage: receiving value } 1 \text { if the farmer participates in a cooperative } \\
\text { and value } 0 \text { otherwise }\end{array}$ & + \\
\hline TRA & $0 / 1$ & $\begin{array}{l}\text { Training: taking the value } 1 \text { if the farmer receives the training on } \\
\text { pomelo growing techniques, and value } 0 \text { otherwise }\end{array}$ & + \\
\hline DIS & $\mathrm{Km}$ & $\begin{array}{l}\text { Distance: taking the value of the road length from the farmer's } \\
\text { garden to the main road }\end{array}$ & - \\
\hline TEL & People & $\begin{array}{l}\text { Telephone: the number of people in the directory that provide the } \\
\text { information related to green pomelo production and consumption }\end{array}$ & + \\
\hline LAB & Percentage (\%) & $\begin{array}{l}\text { Labor: the proportion between direct employees and the total } \\
\text { household members }\end{array}$ & + \\
\hline
\end{tabular}




\section{Methodology}

The logit regression is used to determine factors affecting the market access of green pomelo farmers in Ben Tre Province. Research data were collected using stratified random sampling. The authors used direct interviews to approach 148 pomelo farmers in districts of Chau Thanh, Mo Cay Bac, Giong Trom, and Cho Lach. The logit regression requires the minimum sample size following the formula $n \geq 50+8 p$ (Tabachnick and Fidell, 2007) [9]. In which, $n$ is the minimum sample size, $\mathrm{p}$ is the number of independent variables. Therefore, with 10 proposed independent variables, the ideal sample size is $n \geq 50+8 * 10=130$ observations. So the actual sample size of 148 has ensured the research test requirement.

\section{Research Results and Discussions}

\subsection{Information sources of market access}

According to the survey result in table 2, farmers access to a variety of information sources. The most popular ones are relatives and neighbors (97.97\%), merchants and collectors account for $90.54 \%$. Relatives and neighbors are the groups that farmers have daily contact to exchange information and experiences, so farmers easily access them. Besides, merchants and collectors are farmers' major buyers. Thus, these are two significant sources of information that farmers can access in input and output markets. In addition to this, the information source from television and radio is popular with farmers (68.92\%). However, farmers confirmed that the mass media source of information is for reference purposes only. It is because the purchase prices farmers receive are always lower than the forecasted price. Other market information sources that farmers access are websites, social networks, agricultural material agents, newspapers, magazines, and local extension workers.

Table 2 Market information sources of green pomelo farmers

\begin{tabular}{|l|c|c|}
\hline \multicolumn{1}{|c|}{ Source of information } & Frequency & Percentage (\%) \\
\hline Relatives, neighbors & 145 & 97.97 \\
\hline Merchants, collectors & 134 & 90.54 \\
\hline Mass media & 102 & 68.92 \\
\hline Websites, social networks & 88 & 59.46 \\
\hline Agricultural suppliers & 45 & 30.41 \\
\hline Newspapers, magazines & 42 & 28.38 \\
\hline Agricultural extension officers & 34 & 22.97 \\
\hline
\end{tabular}

\subsection{The understanding level and the cooperation commitment to suppliers/ consumers}

The statistical result in table 3 shows that farmers' level of understanding about input and output providers is relatively high. However, the linkage between the two parties is not sustainable, mostly through words or informal papers. The connection through contracts accounts for a low rate. Accordingly, farmers confirmed that they know well about seed, fertilizer, and pesticide suppliers. The rate of commitment between farmers and these units is $21.62 \%, 59.46 \%$, and $57.43 \%$, respectively. Most of the supplier owners live in the same area and have a long-term partnership with farmers, so they connect by verbal commitments. Farmers' understanding of machinery suppliers and merchants is at an average level. However, the level of commitment to the above subjects is high with the value of $72.97 \%$ and $86.49 \%$. Normally, machines and equipment for the green pomelo cultivation process have a long-time usage and low rate of repeat purchase. This affects the understanding degree of farmers. Although the products have high value, farmers only consider the warranty and the brand reputation when making purchase decisions. 
Table 3 Level of understanding and cooperation commitment to suppliers and consumers

\begin{tabular}{|l|l|l|c|c|}
\hline \multirow{2}{*}{ Suppliers and consumes } & \multicolumn{2}{|l|}{ Level of understanding } & \multicolumn{2}{l|}{ Cooperation commitment } \\
\cline { 2 - 5 } & Mean & Level & Frequency & Percentage (\%) \\
\hline Seed & $4.19 / 5$ & Well, know & 32 & 21.62 \\
\hline Fertilizer & $3.48 / 5$ & Well, know & 88 & 59.46 \\
\hline Pesticide & $3.48 / 5$ & Well, know & 85 & 57.43 \\
\hline Equipment & $2.56 / 5$ & Average & 106 & 72.97 \\
\hline Merchant & $3.32 / 5$ & Average & 127 & 86.49 \\
\hline
\end{tabular}

Note: The 5-level Likert scale is used to assess the understanding level (from 1 - completely unfamiliar, to 5 - well known)

\subsection{Factors affecting farmers' market access}

According to the test result, the significance level (sig.) of the model is high (1\%) and the percentage correct reaches $94.28 \%$. Thus, the model of factors affecting green pomelo farmers' market access is satisfactory.

Table 4 Factors affecting market access

\begin{tabular}{|c|c|c|c|}
\hline Factor & Dy $/ \mathbf{d x}$ & $\mathbf{P}>|\mathbf{z}|$ & Sig. \\
\hline AGE & 0.074 & 0.035 & 0.033 \\
\hline EDU & 0.116 & 0.173 & 0.178 \\
\hline LAB & 0.875 & 0.397 & 0.402 \\
\hline EXP & 0.204 & 0.114 & 0.119 \\
\hline LIN & 3.080 & 0.029 & 0.022 \\
\hline TRA & 3.182 & 0.028 & 0.024 \\
\hline ACR & 0.001 & 0.045 & 0.045 \\
\hline DIS & -0.488 & 0.016 & 0.017 \\
\hline TEL & 0.212 & 0.028 & 0.034 \\
\hline PRO & 0.001 & 0.231 & 0.245 \\
\hline \multicolumn{4}{|c|}{ Sig. } \\
\hline \multicolumn{3}{|c|}{ Percentage correct } & 0.000 \\
\hline \multicolumn{4}{|c}{} \\
\hline
\end{tabular}

According to the result above, out of 10 variables included in the model, farmers' market access is affected by six factors including age, linkage, training, acreage, distance, telephone. The significance levels are all at 5\%. Most of the factors positively impact farmers' market access, except for the "distance" factor. Training is the factor that has the strongest impact on market accessibility with an estimated coefficient of 3.182 and a significance level of 5\%. Production techniques training programs provide market information to orient the most suitable production season for farmers. Training programs are regularly organized by the locality so the above finding is consistent with the reality

\section{Conclusion and Policy Implications}

In general, the market access of green pomelo farmers in Ben Tre Province is still limited. The major sources of information are relatives, neighbors, and collectors. The study has identified six factors affecting farmers' market access which include age, linkage, training, acreage, distance, and telephone. In which, training has the most positive and strong influence on farmers' market access. As a result, several policy implications are proposed to improve the accessibility to the market. 
Firstly, the local authority should open training programs on farming techniques and market approaches for farmers. These programs not only help farmers improve farming skills, enhance productivity and product quality, but also help them be more proactive in access the market and cope with market risks.

Secondly, farmers need to strengthen the linkage with the green skin pomelo supply chain's members, especially the horizontal linkage in production. It can lead farmers to be able to exchange experiences, production techniques, and capital resources. Moreover, this offers farmers more sources of market information to avoid price squeezing. Also, the vertical linkage helps farmers build a commercial commitment in raw material supply and stable output.

Thirdly, farmers should actively learn and improve their market information accessibility from different sources such as the internet, telephone, media, etc. Accordingly, farmers need to study and apply information technology to the production and consumption process. Through the internet, farmers can promptly update the market news, price fluctuations, and manufacturing experiences. In addition to this, the information connection with suppliers and consumers in the directory plays an essential role in improving market access.

Fourthly, the local agriculture and information sector need to coordinate closely to strengthen the dissemination of market information on the mass media to provide official and reliable information for farmers so that they have an appropriate production orientation.

\section{Compliance with ethical standards}

\section{Acknowledgments}

The researchers appreciated all the corrections suggested and recommended by the experts. Special thanks to the respondent farmers for their cooperation and participation during the research. This research received no precise funds from any agency in the public or private sectors.

\section{Disclosure of conflict of interest}

The authors declare that there are no competing or potential conflicts of interest

\section{References}

[1] Kleih U, Odwongo W, Ndyashangaki C. Community Access to Marketing Opportunities: Options for Remote Areas. Natural Resources Institute, University of Greenwich, Chatham Maritime, UK. 1999.

[2] Cuong TH. Market Access and Agricultural Productivity in Vietnam. 2005.

[3] Bly RW. A perfect guide to market approach. Hanoi: Labor Publishing House. 2006.

[4] Van Schalkwyk HD, Kotze NA, Fourie P. Linking rural economies with markets-an institutional approach. In 16th International Farm Management Association Congress A Vibrant Rural Economy-The Challenge For Balance. $2007 ; 229$.

[5] Yamano T, Kijima Y. Market Access, Soil Fertility, and Income in East Africa. In Emerging development of agriculture in East Africa. 2011; 187-202.

[6] Amaya N, Alwang JR. Access to information and farmer's market choice: The case of potato in highland Bolivia. Journal of Agriculture, Food Systems, and Community Development. 2011; 1(4): 35-53.

[7] Kuma B. Market access and value chain analysis of dairy industry in Ethiopia: The case of Wolaita Zone. Doctoral dissertation. Haramaya University. 2012.

[8] Nghi NQ, Nam MV. Market accessibility of pineapples growing households at Tan Phuoc District in Tien Giang Province. Can Tho University Journal of Science. 2014; 35: 24-31.

[9] Tabachnick BG, Fidell LS. Using Multivariate Statistics (3rd ed.). New York: Harper Collins. 1996. 